\title{
住宅居間における光環境と家具配置の関係 RELATIONSHIP BETWEEN LIGHTING ENVIRONMENTS AND FURNITURE ARRANGEMENTS IN A LIVINGROOM
}

\author{
小林茂 雄*, 村中 美奈子** \\ Shigeo KOBAYASHI and Minako MURANAKA
}

\begin{abstract}
The purpose of this research is to seek the relationship between lighting environments and furniture arrangements in a living dining room. In an experiment, five lighting environments were presented to subjects, and they were asked to arrange tables, chairs and a sofa freely.

As a result of the experiment, it was revealed to be common for all subjects to put the dining table on the kitchen side and put the sofa in a position on the wall side away from the kitchen in the general lighting. When the room was illuminated non-uniformly and the lighting area was separated from the kitchen, some subjects tried to put the dining table in the vicinity of the lighting, and others did not change the position. For subjects who had changed the position of the dining table according to the lighting condition there, tended to be a strong relationship between eating behavior and brightness. On the other hand, subjects who did not change the position of the dining table even if the lighting condition changed tended to value the convenience of the positional relationship in the room, and tried to change behavior location to adjust to the lighting.
\end{abstract}

Keywords: furniture arrangement, non-uniform lighting, living dining room, individual difference, experiment with a model 家具配置、不均一照明、リビングダイニングルーム、個人差、模型実験

\section{1. 研究の背景と目的}

住宅のリビングルームでは、食事をする、本を読む、TVを見るな ど様々な行為がなされ、それぞれの行為に対して適している環境条 件がある。それは、キッチンからコミュニケーションが取れる場所で 団欒したいという位置に対する条件や、明るいところで食事をしたい といら光に対する条件などである。こうした位置や光に対する条件 は、通常、別々に取り上げられる。例えば、ショールームやモデ ルハウスにおいて、行為に合ったリビングルームの光環境を提示す るとき、家具の位置を固定した状態で照明パターンを変え、家具の 位置を移動させるようなことはしない。しかし、部屋をどのように使 うか、家具をどのようにレイアウトするかは、個人によって差がある ものである。そして、ある家具レイアウトのときに好ましい光の状態 が、別のレイアウトのときにも好ましいとは限らず、同時に、ある照 明パターンのときの家具レイアウトが別の照明パターンのときにも適 しているとは限らない。特に、部屋を不均一に照明するときには、 照明の位置と家具の配置は連携して考えなければならないであろう。 本研究では、住宅のリビングルームにおける家具配置の仕方や時 間の過ごし方を基に、行為に適した光環境のあり方を探ることを目的 としている。具体的には、あるリビング・ダイニングルームにおいて 複数の光環境を被験者に提示し、テーブルや椅子などを自由に配
置してもらう実験から、その被験者の持つ傾向を読み取ろうとする。 光の条件によって家具の配置をどの様に変えるかをみることで、行 為の仕方を光の位置に合わせる被験者や、光環境よりもあくまで使 い勝手を優先する被験者など、個人個人の要望を把握できるものと 思われる。本研究は、光環境と家具の配置がどのように結びつい ているかを把握するものであり、最適な光環境の条件や家具配置の 条件を求めるものではなく、また両者の最適な組み合わせを求める ものでもない。

住宅の行為と光環境に関する既往研究として、室内照度に対する 満足度を明らかにしようとしたもの1)、リビングルームでの行為に対 する適した照度レベルや不均一さを明らかにしようとしたもの2〜5) がある。前者の研究は、作業別の全般照度や作業面照度と満足率 との関係を求めているものの、照度の不均一さや個人差を積極的 には扱っていない。後者の研究では、不均一に照明することを前 提としているが、行為の位置や家具配置と光の位置との関係は調べ られていない。光の種類と家具配置との関係については、空の形 態による椅子の好ましい位置を実験的に求めたもの ${ }^{6)}$ があり、空に 対する好みと部屋の中での配置に対する好みが複合して椅子の位 置が決められていることを示している。また筆者らは、カフェの内装 色による家具の色彩や配置の仕方を調べている7)。しかしこれら 
は、自分の生活空間や生活行為を設定したものではなく、また空間 の中での照明の位置を実験条件としはしていない。

本研究の特徵として、日常的な行為をするリビング・ダイニング ルームを対象として光環境と家具配置との関係を不均一な照明条件 において検討すること、光環境と家具配置との結びつきに関する個 人差を明らかにしようとすることが挙げられる。

\section{2. 実験概要}

図1、2のような、キッチンとリビング・ダイニングルームのある1/ 10 縮尺模型を製作した。部屋の規模は $7 \mathrm{~m} \times 4 \mathrm{~m}$ の $28 \mathrm{~m}^{2}$ (キッチン を含めると $\left.40 \mathrm{~m}^{2}\right)$ とした。幾つかの大きさで予備実験を行ったとこ ろ、 $4 \mathrm{~m} \times 4 \mathrm{~m}$ や $5 \mathrm{~m} \times 4 \mathrm{~m}$ の部屋では家具配置と光環境にバリエー ションを持たせられにくかったことから、それらよりやや大きなサイズ とした。ただし、矩形に近い形状では家具配置がばらつきすぎる傾 向にあったため、キッチンからの距離を長めにとることで、その方向 での家具配置の特徵を主に取り出すこととした。この部屋の中にダ イニングテーブル(以下 DT)と椅子、ソファ(以下 S)、ソファテーブ ル(以下ST)、TVの5種類8個の家具を自由に配置する実験とした。 模型の内装・家具の色彩と反射率を表 1 に示す注1)。

照明条件は、(1)全般照明、(2) 3 灯片側照明、 (3) 2 灯斜配置 照明、(4) 1 灯中央照明、(5) 1 灯空側照明の5種類とした。これは、 予備実験から選定したもので、照度の均一さ、照明範囲の違い、 照明位置の違いに変化を持たせたものである。(1)〜(5)は床面照度 の均齐度の高い順としている。光源の色温度を表 2 に、各部屋の 照明条件を表 3 に示す。照度レベルは、模型上で好ましいと思わ れる明るさを基に設定しており、実空間での好ましい照度レベルと は必ずしも対応していない。(1)全般照明と(4)1灯中央照明で中央 にDTを置き、被験者に光源の強さを調節してもらったところ、どち
らの照明条件でもテーブル中央が約 $50(1 \mathrm{x})$ のときに適切な明るさと された注2)。

被験者に提示する条件として、集合住宅の2階に位置するリビン グ・ダイニングルームに、自分の家族と暮らしているとものした注 3 。 また、設定時間は夜 19 時〜 23 時、照明方法は照明条件ごとに固 定されていて、それ以上光源を追加したり減少させたりすることなど の変更はできないものと教示した。実験は被験者一人ずつ行った。 はじめに被験者の属性などのインタビューを行い、次に全ての照明 条件を提示した。実験室に入室してから約 10 分が経過後注4)、一 つの照明条件に設定して、家具を自由に配置してもらう実験を行 なった。このとき、家族の好みを考えず、自分の好みだけで位置 を決定するように教示した注5》。配置が終了後、家具配置の理由に ついて、部屋のどこでどの程度の時間を過ごすかについて、照明 や家具配置を含めた部屋の満足度についてのアンケートを行った。 満足度は、「満足」〜「不満」までの 5 段階とした。照明条件の 提示順は被験者により変えている。被験者は大学生 25 名(男性 11 名、女性 14 名) であり、無空の暗室で実験を行った。家具を配 置する際は、図2の手前の壁を外して作業し、また必要に応じて左 のキッチン側の壁や右の開口部を外して、様々な角度から模型を眺 められるようにした。一人にかかった実験時間は、1 時間〜2時間 半であった。

\section{3. 実験結果}

\section{1 家具配置の全体的傾向}

図3に、全被験者の家具の位置を、照明条件ごとに重ねて示して いる。照明条件(2)〜 (5)では、床面照度 $20(1 \mathrm{x})$ 以上を点線で囲って おり、この範囲を照明下と呼ぶこととする。図4は、部屋で過ごす 場所と時間を尋ねたアンケート結果を、時間の割合を用いて示して

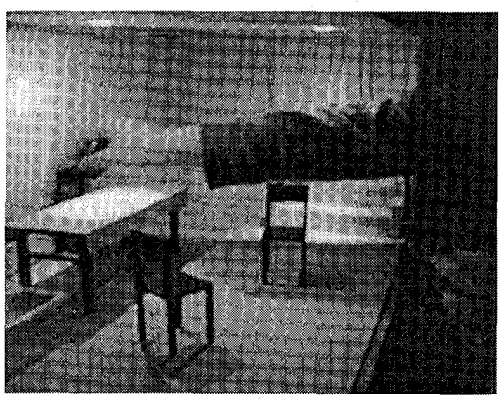

図 1 家具配置風景

表 2 光源の色度と色温度

\begin{tabular}{|c|c|c|c|}
\cline { 2 - 3 } \multicolumn{1}{c|}{} & \multicolumn{2}{c|}{ 色度 } & \multicolumn{1}{c}{} \\
\hline 光源 & $x$ & $y$ & 色温度(K) \\
\hline ナツメ球 $(15 W)$ & 0.486 & 0.430 & 2500 \\
\hline LED3灯 (0.7W) & 0.298 & 0.316 & 5500 \\
\hline
\end{tabular}

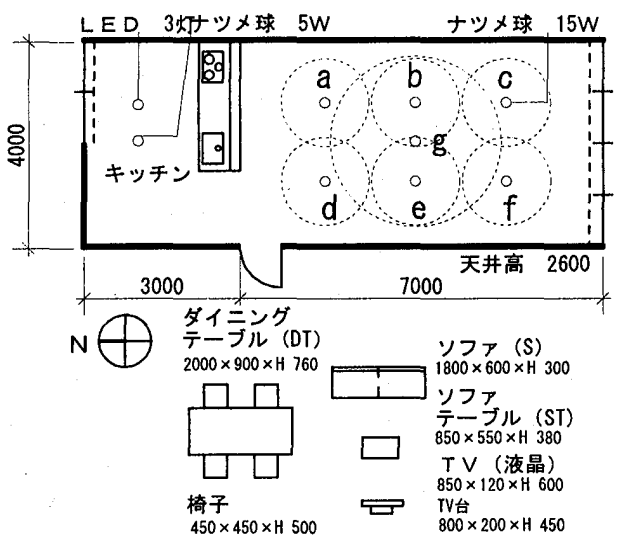

図 2 縮尺模型の図面 数值は実寸 $(\mathrm{mm})$ を表す
表 1 内装・家具の色彩と反射率

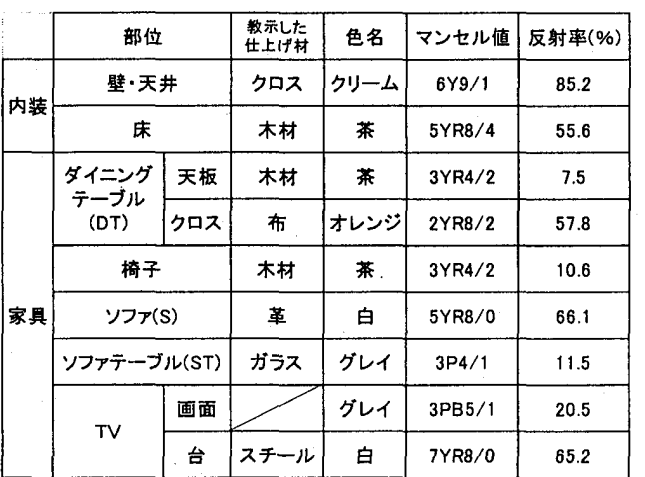

ST とTVの画面と台以外は、光を搪散するマットな用紙を用いた。

表 3 照明条件表(床面照度)

\begin{tabular}{|c|c|c|c|c|c|c|c|c|c|c|c|c|c|}
\hline \multirow{2}{*}{ 照明条件 } & \multirow{2}{*}{ 点灯箇所 } & \multirow{2}{*}{ 平均照度(Ix) } & \multirow{2}{*}{ 最高照度(Ix) } & \multirow{2}{*}{ 最低照度(Ix) } & \multicolumn{7}{|c|}{ 各位置の照度(光源直下)（|x) } & \multirow{2}{*}{$\begin{array}{c}\text { キッチン } \\
\text { 中央照度(1x) }\end{array}$} & \multirow{2}{*}{ 均斉度 } \\
\hline & & & & & a & b & $\mathrm{c}$ & $d$ & e & $f$ & $\mathrm{~g}$ & & \\
\hline (1) (全般照明) & $a, b, c, d, e, f$ & 36.2 & 72.9 & 12.0 & 69.8 & 72.9 & 68.9 & 65.5 & 68.5 & 64.0 & 57.1 & 23.6 & 0.17 \\
\hline (2) ( 3 灯片側照明) & $a, b, c$ & 18.5 & 57.4 & 6.5 & 55.2 & 57.4 & 55.0 & 13.2 & 14.5 & 13.0 & 21.7 & 21.9 & 0.11 \\
\hline (3)(2灯斜め配置照明) & $b, f$ & 12.6 & 48.1 & 4.3 & 11.0 & 48.1 & 14.1 & 7.2 & 12.7 & 47.7 & 16.1 & 20.6 & 0.09 \\
\hline (4) (1灯中央照明) & $\mathrm{g}$ & 11.8 & 47.6 & 4.3 & 10.7 & 40.5 & 9.5 & 8.9 & 26.1 & 7.7 & 47.6 & 20.7 & 0.09 \\
\hline (5)（1灯悹側照明） & c & 6.2 & 44.9 & 1.3 & 3.6 & 7.4 & 44.9 & 2.6 & 4.2 & 6.2 & 6.0 & 20.3 & 0.03 \\
\hline
\end{tabular}


いる。図5は、全被験者の家具配置を個別に示したものである。図 5から、DTと椅子は一体となって配置されており、離して配置され ることはほとんどないことが分かる。また部屋で過ごす位置の指摘 は、DTかSを示すものが多く、DT周りの椅子を具体的に指示す る被験者はほとんどいなかった。そこで、家具配置の中で、DTと $\mathrm{S}$ の 2 つ位置を主に取り上げることとした。表 4 に、全被験者の DTとSの配置位置の座標平均値を示している。

照明条件(1)(全般照明)では、25名の被験者全員がDTをキッチ ン側 $(\mathrm{x}$ 軸上 $0 \mathrm{~m} \sim 3.5 \mathrm{~m}$ ) に配置しており、配置位置はあまりばらつ いていない。STは全て部屋 中央よりも空側に配置され ている。TVとSの配置範 囲はDTやSと比べて広 がっている。これは、両者 がSTを挟むように対角線 上に置かれることが多く、 その傾きが被験者によって 差があるためである。部屋 全体が照明されている条 件では、どこでどの様な行 為をするにも明るさに不足 がないため、光に拘束さ れることなく自由な家具配 置が生まれるのではない かと考えられたが、配置パ ターンの多くは類似したも のであり、特にDTの位置 の個人差は小さいもので あった。また図4の部屋で 過ごす時間をみると、Sで の割合が比較的大きいこと が分かる。

照明条件(2) (3灯片側照 明)は、部屋の長辺方向の 片側が照明されているパ ターンである。(2)〜(5)の条 件の中では最も照度の均

表 4 家具の配置位置の全 被験者平均

\begin{tabular}{|c|c|c|c|c|c|}
\hline \multirow{3}{*}{$\begin{array}{l}\text { 照明 } \\
\text { 㷊件 }\end{array}$} & \multicolumn{4}{|c|}{$\begin{array}{c}\text { 家具の配置位置の } \\
\text { 平均 }(\mathrm{m})\end{array}$} & \multirow{3}{*}{$\begin{array}{c}\text { DTとs } \sigma \\
\text { 距離 } \\
\text { 平均 } \\
(\mathrm{m})\end{array}$} \\
\hline & \multicolumn{2}{|c|}{ DT } & \multicolumn{2}{|c|}{$\mathrm{s}$} & \\
\hline & $x$ & $y$ & $x$ & $y$ & \\
\hline (1) & 1.7 & 2.8 & 5.1 & 2.4 & 3.4 \\
\hline (2) & 1.8 & 2.7 & 5.0 & 2.5 & 3.3 \\
\hline (3) & 2.2 & 2.7 & 4.9 & 2.0 & 2.7 \\
\hline (4) & 2.0 & 2.5 & 5.0 & 2.3 & 2.7 \\
\hline (5) & 2.4 & 2.7 & 4.5 & 2.6 & 2.1 \\
\hline
\end{tabular}

※家具の中心の位置を示す
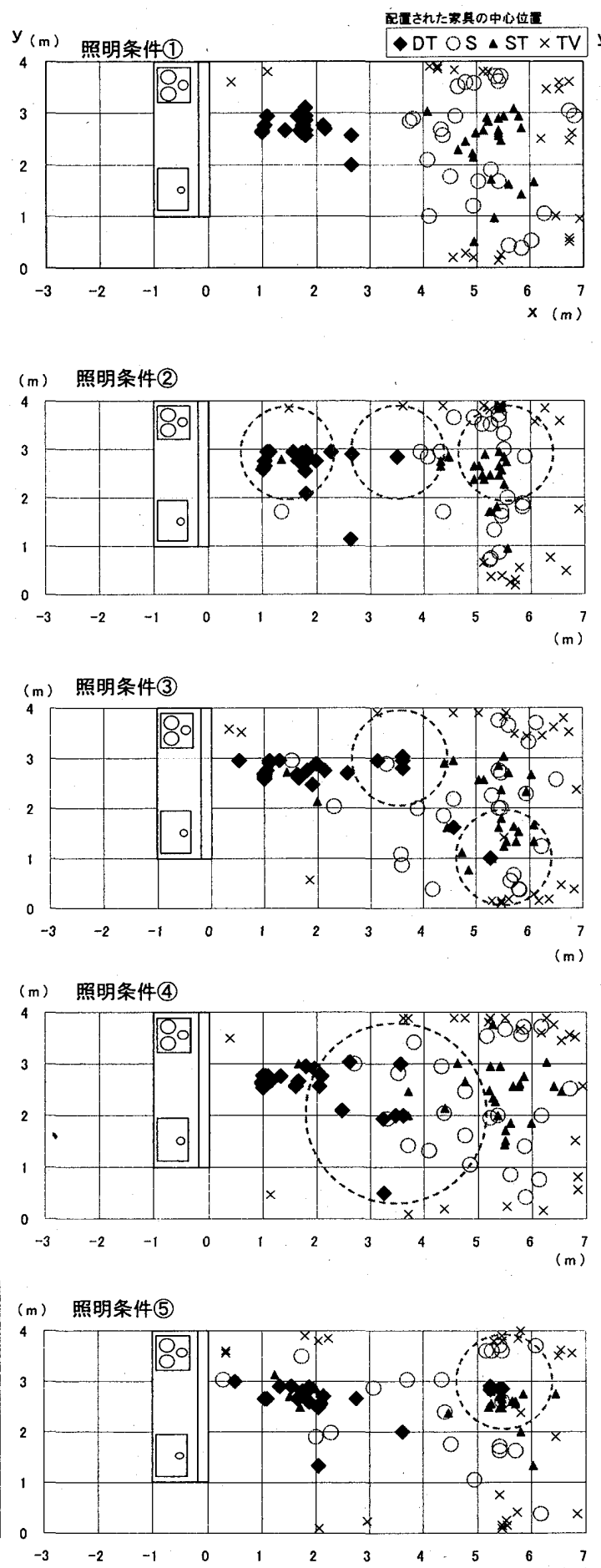

図 3 家具の配置位置

※図内点線の円内は床面照度20(1x)以上
斉度が高い。DTをキッチン側に配置する者は 24 名で、1名が中 央のやや空側に配置している。 ST の配置は $\mathrm{x}$ 軸の $5 \sim 6 \mathrm{~m} 、 \mathrm{y}$ 軸 の $2 \sim 3 \mathrm{~m}$ に集中している。また、24名が DTを照明下(家具の中 心が床面照度20(1x)以上)に配置しており、14名がSを照明下に配 置している。条件(2)の照明では、(1)の全般照明と同様に、DTは キッチン寄り、Sは空側に離れて配置されると共に、それらの家具 が照度の高い場所に置かれる傾向があるといえる。

照明条件(3)(2灯斜め配置照明)は、部屋中央と空側のダウンライ トを一灯ずつ点灯したものである。DTをキッチン側に配置する者が 
照明条件(1)

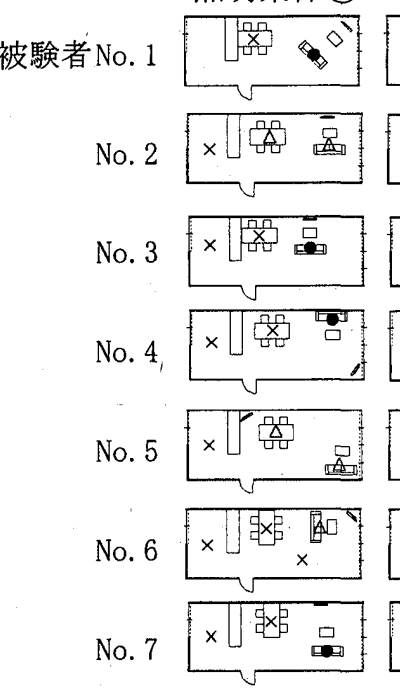

No. 8

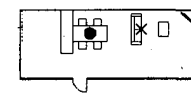

No. 9

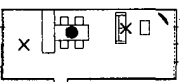

No. 10

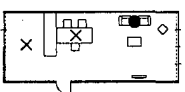

No. 11

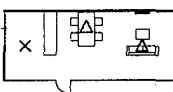

No. 12

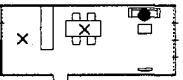

No. 13

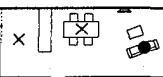

No. 14

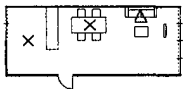

No. 15

$\times$ 究

No. 16

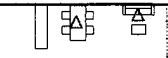

No. 17

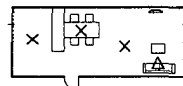

No. 18

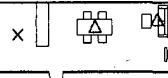

No. 19

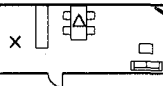

No. 20

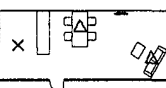

No. 21

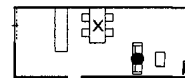

No. 22

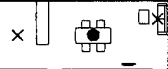

No. 23

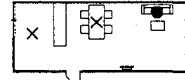

No. 24

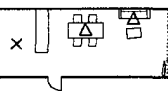

No. 25

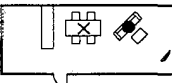

(2)

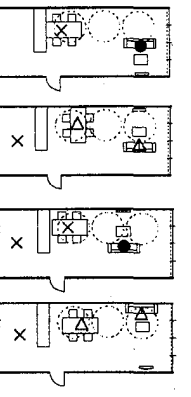

(3)
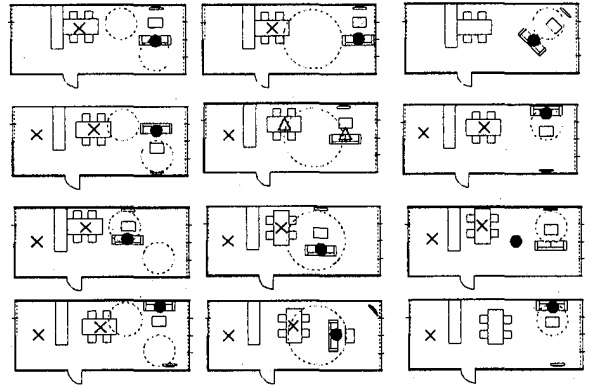

\begin{tabular}{r|r|}
\hline$x$ & $2 x: x$ \\
\hline
\end{tabular}

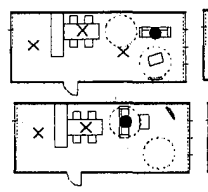

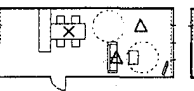
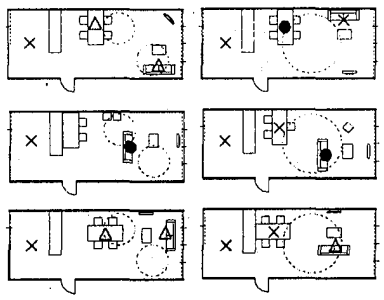

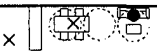
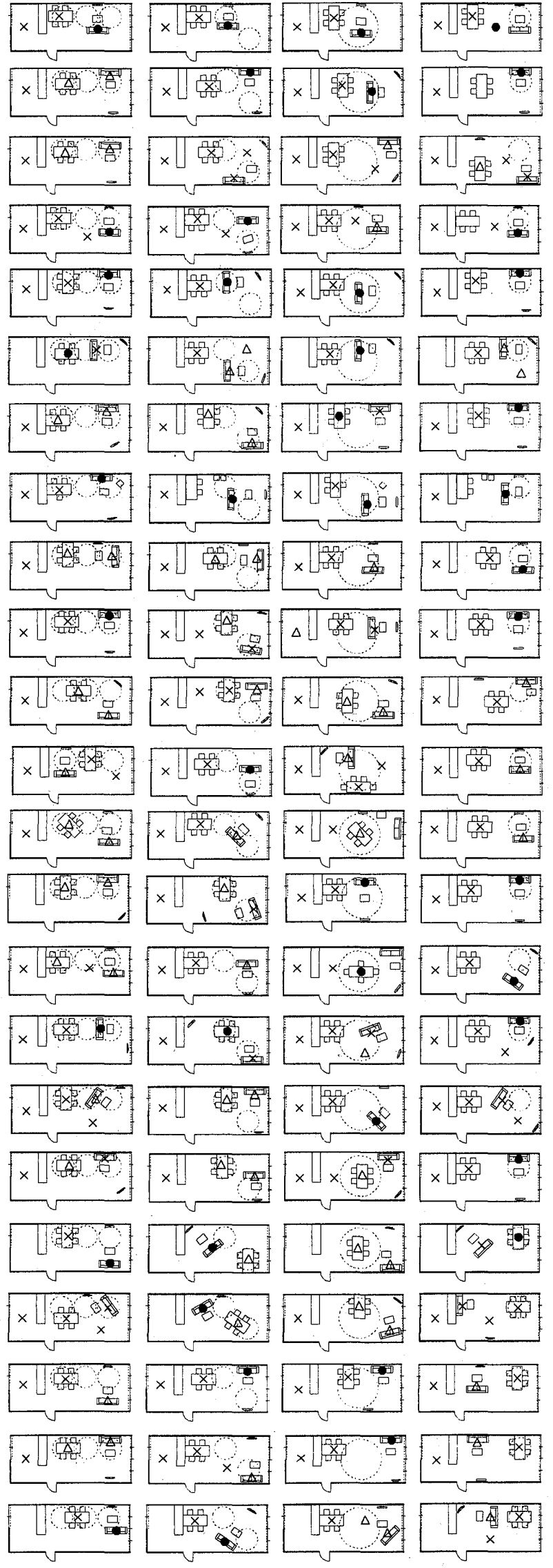

17 名で、 $\mathrm{x}$ 軸上 $0 \sim 6 \mathrm{~m}$ の間に広く配置さ れている。条件(1)や(2)よりもキッチンから 離れていることが多いのは、照明の位置に 引っ張られたものと考えられる。SやSTは (1)(2)と同様に、中央より空側に配置される ことが多いものの、その範囲は広がってい る。これは、DTが中央の光源 bに近寄る 一方で、Sは図中右下の光源的近づいた ためではないかと考えられる。Sを照明下 に置く者は 8 名で、17 名は照明下ではな い。また図 4 より、長い時間を過ごすのは Sであることが多いことと、それは照明下で はない場合が多いということが分かる。

照明条件(4) (1灯中央照明)は、中央の ダウンライを点灯した条件である。1灯では あるが、床面が20(1x)以上となる範囲は他 の照明よりも広い。DTをキッチン側に配置 した者が19名であり、またDTを照明下に 配置した者は7名である。Sは部屋中央か ら空側の広い範囲に配置されている。照 明条件(1)と比較して、真中付近への家具 の分布がみられ、かつそのばらつきが大 きいといら特徵がある。この原因として、部 屋の中央の照明に家具の位置が引き寄せ られることと、照度の高い範囲が比較的大 きいことで位置の選択肢が増えることなどが あると考えられる。図4より、照明下でのS やDTで、長時間過ごす者が多いことが分 かる。

照明条件(5) (1灯空側照明)は、光源が キッチンから最も遠い位置にある条件であ る。DTをキッチン側に配置する者が 20 名 で、5名が空側に置いている。この5名は 全てDTが照明下となっており、明るい場所 に配置するためにキッチンと離れたものと考 えられる。また、STを照明下に置く者は16 名と多い。これは、DTを照度が低いキッ チン側に配置した被験者であり、DTの代 わりにSTを明るい場所に置いたのではな いかと推測できる。長時間過ごすのは、照 明下とその近傍の、S D D T゙ある。

以上の結果から、部屋全体が明るい照 明ではキッチン側にDTを置き、壁側の離 れた位置にSを置くことが被験者に共通し ていること、照明を離してキッチン側を暗く すると、明るい場所にDTを置こうとする傾

\section{部屋で過ごす時間の割合 \\ $\times \sim 30 \% \quad \triangle 30 \sim 50 \%$}

図 5 全被験者の家具配置と過ごす時間 
表 5 被験者ごとの家具配置の特徵（DTを中心として）

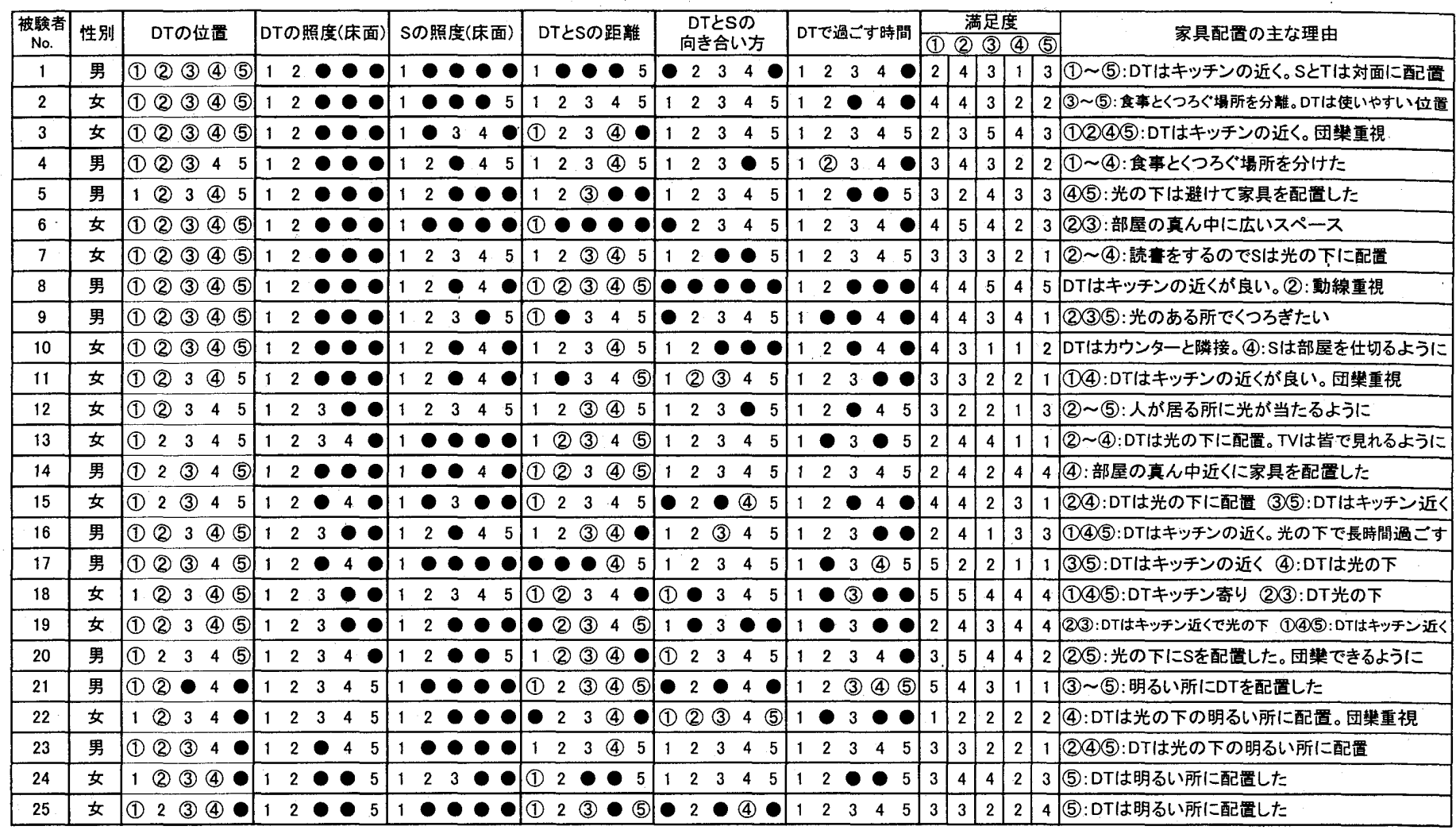

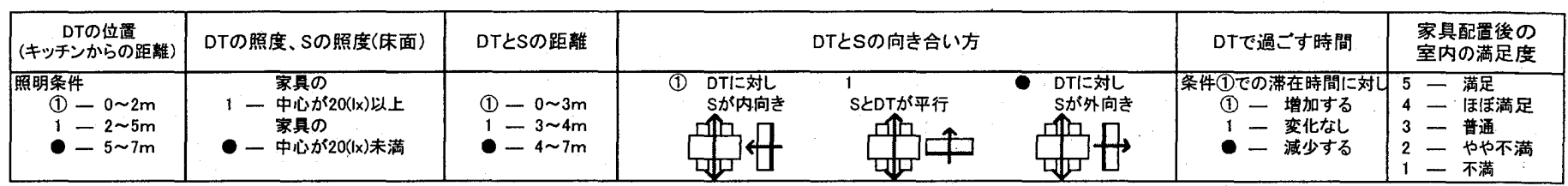

向があること、そしてその場合には配置の個人差が大きくなるという ことが分かった。

\section{2 家具配置の個人差}

\section{2 .1 照明条件によるDTの位置の変化}

実験中に被験者が家具を配置するとき、DTの位置を最初に決め る被験者が最も多かった（照明条件により、17〜21名）。また配 置後のアンケートでも、DTの配置理由を述べることが多かった。こ れらのことから、家具配置の中でDTの位置の決定が最も重視され ていることが推測される。そこで、照明条件による家具配置の変わ り方の個人差について、主にDTの位置の変化の仕方に着目して 検討することとした。

表 5 は被験者別に、DTの位置やその床面照度、家具配置後の 満足度などをまとめたものである。被験者番号は、(1)〜(5)の照明条 件の中で、DTの位置が最も離れている 2 条件での距離が短い順 となるようにつけたものである。この距離を家具配置の変化の大きさ を代表させるものとして、被験者を 3 つのグループ（No.1〜 11、 No.12〜20、No.21～25）に分け、その傾向をまとめることとし た。また、各グループの中から、被験者を1名ずつ選出して、家 具を配置する際に光環境との関係について考えたことと、部屋での 具体的な過ごし方について、改めてインタビューを行なった。図6に その結果を示す。

\section{（1）DTの移動が小さい被験者}

被験者No.1〜11は、照明条件によってDTを移動させる距離が 短いグループである。図5より、全ての照明条件でDTをキッチン 側 $(\mathrm{x}$ 軸上 $0 \sim 3.5 \mathrm{~m}$ ) に配置していることが分かる。表 5 より、照明 条件(1)と(2)ではDTの (中心の床面) 照度は $20(\mathrm{Ix})$ 以上であるが、 照明の位置がキッチンから離れる条件(3)(4)(5)では、DTの照度は $20(1 \mathrm{x})$ 末満となっている。表 5より、家具配置の理由として「DTは キッチンに近い方が良い」，No.9以外の被験者全員が述べてお り、光の状態に関わらず優先させていることが分かる。

図6における被験者No.4は、このグループの代表である。家具 の向きは条件によって多少異なっているものの、家具の位置はどの 照明条件においてもほぼ同じである。DTをキッチンの近くの使い やすい場所に置くことを最も重視している。行為の場所や時間は、 条件(1)(3)(4)は類似している。条件(2)では、DTの明るさが「ゆっ たりと食事できる」と述べており、そこで過ごす時間も長くなってい る。一方、DTに光が当たらない条件(5)では、食事を含めたほと んどの行為をSで行うとしており、「DTはあまり使わない」としてい る。これらのことからこの被験者は、照明条件によって家具の位置 を変えるのではなく、家具はそのままで行為の場所や時間を調整し ているものといえる。こうした傾向は、被験者No.2、6、9でもみ られた。 
被験者No.4 照明条件による家具配置の変化が少ない被験者の例

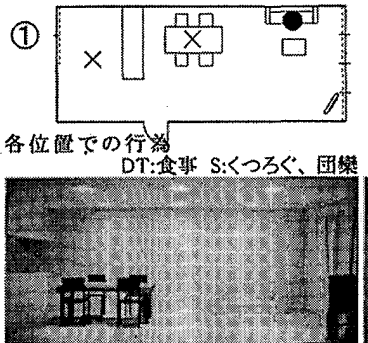

DTが少し明るすぎるため、ゆっ たりと食静でざな。Sの方が くつろげそう。DTとキッチンの移 動を短く。

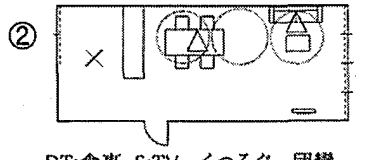

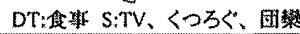

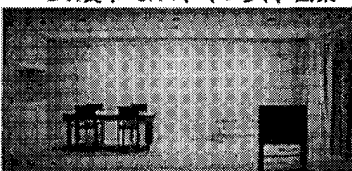

これ位の少し暗めのガがゆっ たりと传事ができる。DTで過 ごす時閒が辰くなりそう。
(3)

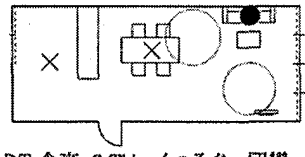

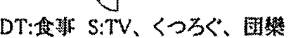

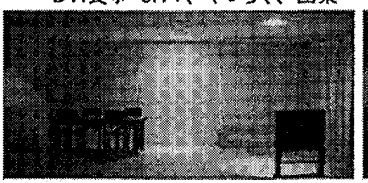

DTを少し中央第りにした。食事 をするには机上面が睹いが、を れでも明るい場所よりはキッチン の近<加上い
(4)

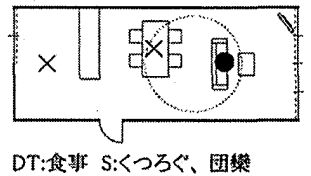

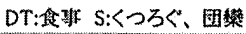

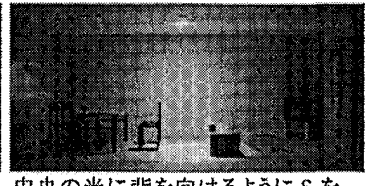

中央の光に背を向けるようにらを 配證した。DTを光に近つけた が、これ以上はキッチンと離し たくない。
(5)

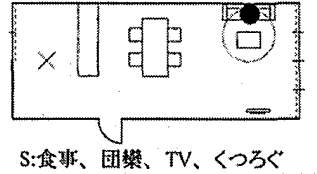

S:食报、国颕、TV、くつろく

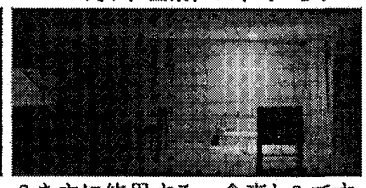

S衣主に使用する。令事事与です ることが多い。DT㤝あまり使わな いと思うが、ここにあるのが便利。

\section{被験者No.16 照明条件によって家具配置にやや変化がみられる被験者の例}

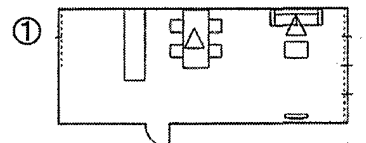

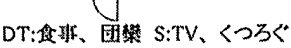

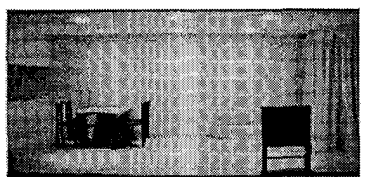

使い勝手と動線を面視して配登 した。部屋全体を揵う感じ。DT はキッチン近くが使いやずい。
(2)

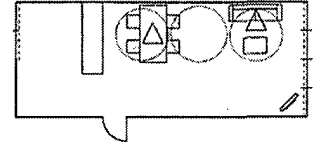

DT:伶非、间樂 S:TV、くつろく

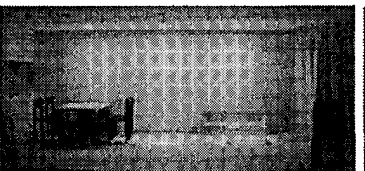

部瓷全体の明るさが丁度よい。 光のある腤側に人がいる场所を つくるうにした。

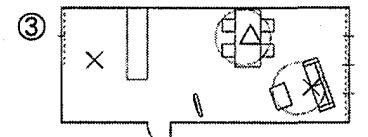

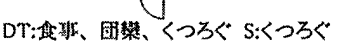

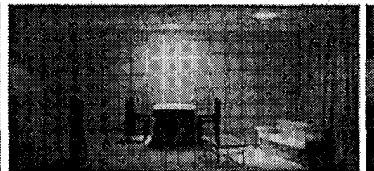

DTとSの雨方を光の下に配溫 した。DTはもう少しキッチンと近 くの方が良かったが仕方ない。
(4)

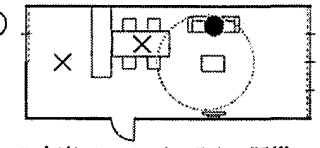

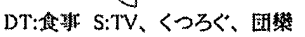

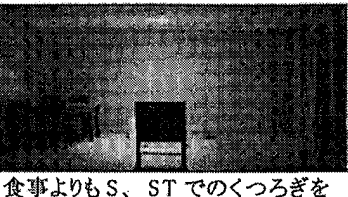

食事よりもS、ST でのくつろぎを 荲視したため、Sに光が当たる ように配填した。
(5)

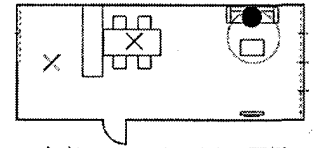

DT:令耕 S:TV、くつろぐ、因樂

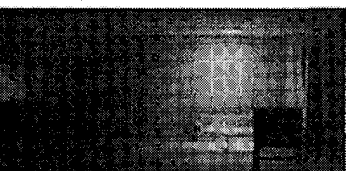

S、STでのくつろ民をを辰先させ て光の下に配睡した。DTH キッチンの近くにした。暗ずぎる が繁圈氛は䈍くない。

被酫者 No.21 照明条件によって家具配置の変化が大きい被験者の例

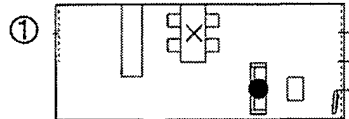

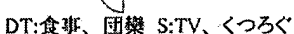

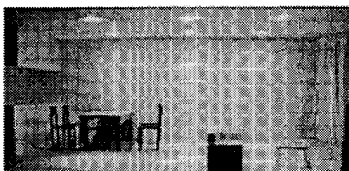

DTは使い勝手を考えてキッチン の近くに配㩊した。DTもSもこ二 でなければいけないわけではな い。

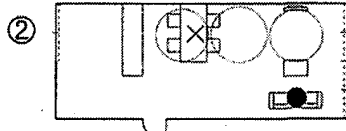

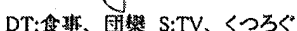

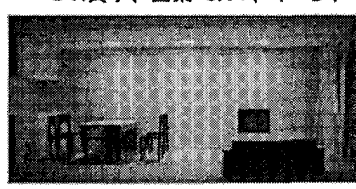

部屋金体の朋るさが丁庋良い。 DTは使い腾手加らキッチン側 に配登した。Sは明るすぎな 墈可に。

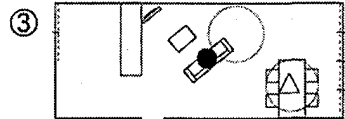

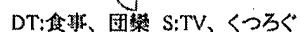

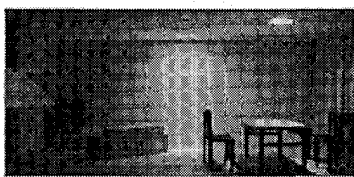

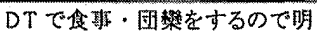

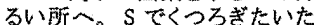
め明るすぎず広い場所に配经し
(4)

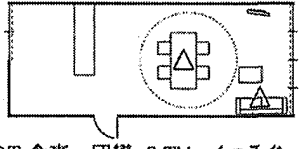

DT:食啅、团燓 S:TV、くつろぐ

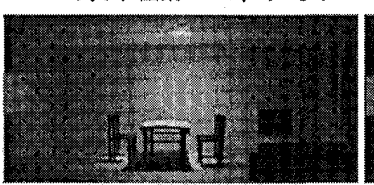

明るさが必緊なDTだけを明るい 中央に配㨁した。周りが暗ず゙ て部犀全体を使えない。

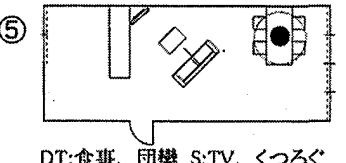

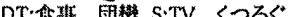

図 6 被験者へのインタビュー結果

\section{（2）DTをやや移動させる被験者}

被験者No.12〜20は、照明条件によってDTの配置をやや変え ているグループである。図 5 と表 5 より、照明条件(3)(4)では、DT をキッチンから離して照明に近づける被験者が多く、照度も約半数 の被験者が20(1x)以上を確保している。しかしキッチンと照明位置 が離れている条件(5)では、全員がDTを中央よりキッチン側に配置 しており、照度も20(lx)未満となっている。こうした傾向は、DTの 配置理由が照明条件によって異なっていることにも表れている。例 えば被験者No.17は、条件(3)(5)では「DTはキッチンの近く」とし ているが、条件(4)では「ご飯は明るい所が良いのでDTは光の下」 としている。No.15、16、18、19も同様な傾向がみられる。これ らの被験者は、照明の位置に家具配置をある程度合わせるもの の、合わし切れない条件の場合には、キッチンなどとの位置関係を 優先するものと考えられる。

図6における被験者No.16 は、このグループの代表である。基 本的に、「DTをキッチンの側に配置する」ことと「明るい場所にDT、

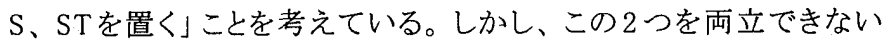

条件 (3)(4)(5)では、家具の置く場所に関して葛藤がみられている。 照明条件(3)ではDTを明るい空側へ寄せているため、キッチンとの 近さを犠牲にしている。一方条件(5)では、条件(1)(2)のようにDTを キッチンに近づけているため、明るさを犠牲にしている。ただしこの 場合、暗いDTについて「雾囲気は悪くない」と述べており、満足 度評価值も3と低くはなっていない。このことから、この被験者はDT を明るくすることが満足するための必要条件ではなかったということが 読み取れる。これと類似した傾向は、被験者No.12、14、18、19 でもみられ、条件(5)でDTを暗い場所に配置しているものの満足 度は高くなっている。一方、被験者No.14、20は、条件(4)でDT をキッチンから離れた明るい場所に配置しているときに満足度は高く なっている。これらの被験者は、DTをキッチンの側に配置すること が必要条件ではなかったものと推測できる。

\section{（3）DTの移動が大きい被験者}

被験者No.21〜25は、照明条件によってDTの配置を大きく变 えているグループである。照明の場所に合わせてDTを配置するた め、条件(5)では、全員がDTをキッチンから離れた位置に置いて 
いる。全ての被験者が「DTは明るい所に」と理由を述べているこ とから、食事をする行為と照度の高さとの結びつきが強いといえる。

図 6 における被験者No.21 は、このグループの代表である。照 明条件(1)(2)ではDTをキッチン側に、条件(3)(5)では空側の照明下 に、条件(4)では中央の照明下に配置している。DTを含めた家具 の位置を移動させることの抵抗に関することは述べなかった。照明 条件(4)(5)では満足度評価值は1 と低いが、その理由として、部屋 の大部分が暗すぎることを挙げている。条件(1)～(3)では明るさにつ いての不満はなく、この被験者は部屋全体がある程度明るいことを 重要な評価要因としていることが分かる。このグループの他の被験 者も、家具を移動させることの抵抗は小さいものと考えられる。ただ し、表 5 より、どの照明条件の満足度が高くなっているかは一致し ているわけではなく、DTを明るくすることの次に重視していることに は差があるものと考えられる。

\section{2 .2 DTとSとの関係}

DTとSの向きについては、図5と表 5 より、全体的に両者を平行 に配㯰している者が多く、照明条件による特徵はみられなかった。 ただし、被験者による差異は生じている。No.8は全ての条件で外 向きに配置しており、No.10、19、21、25 は、3つの条件で外 向きに配置している。表 5 より、両者が外向きに配置されるのは、 DTとSとの距離が $3 \mathrm{~m}$ 以内と短い場合に多いことから、2つの家具 の近さを向きによって緩和しているのではないかと考えられる。一 方、No.11、22は、DTとSを内向きに配置する傾向にあり、No.3、 13、14 はDTとSの向きは平行であるが両者の距離を比較的短く している。こうした被験者は共通して、団欒を重視する」と述べる 傾向にあり、家族でのコミュニケーションのとり方がDTとSの向きや 距離に反映されたものと考えられる。

\section{4. まとめと展望}

本研究では、リビング・ダイニングルームの模型において複数の光 環境を被験者に提示し、テーブルや椅子などを自由に配置してもら う実験から、被験者の持つ光環境と家具配置の結びつきの傾向を 読み取ることを行った。実験の結果、全般照明ではキッチン側にダ イニングテーブル（DT）を置き、壁側の離れた位置にソファ (S) を置くことが全ての被験者に共通していること、キッチン側を暗くして 照明する場所を離した場合には、照明の近辺にDTを置こうとする 傾向があること、そしてその場合には配置の個人差が大きくなるこ とが分かった。

次に、家具の配置位置の個人差に関わる要因を把握するため、 DTの位置に着目して検討した。その結果、照明条件が変わって もDTの位置を変えない被験者は、位置関係の持つ利便性を重視 しており、家具の配置は余り変えないで行為の場所や時間を調整す ることなどが分かった。一方、照明条件によってDTの配置を大きく 変えている被験者は、家具の位置を変えることの抵抗は比較的小さ く、食事をする行為と照度の高さとの結びっきなどが強いということ が分かった。

このような光環境と家具配置の結びつきの個人差は、不均一な光 環境を計画するときの進め方などに反映させられるのではないかと 考えられる。例えば、部屋の中の位置関傒に強いこだわりを持つ ような被験者には、行為の場所や家具の位置をはじめに決定して から、どの場所にどの様な光を与えるかを計画するのが効率的であ
ろうと思われる。一方、照明条件によって家具配置を変えるような被 験者は、光環境と家具配置を平行して検討していくのがよいと思わ れる。少なくとも、照明パターンだけを変えて提示するのは問題が あるであろう。行為と明るさとにどの様な結びつきがあるかを把握し ておくと、一般的なものとは異なる家具配置で、かつその個人に適 したバリエーションの豊かな光環境が計画されやすくなるのではない かと考えられる。

\section{謝辞}

本研究は、武蔵工業大学建築学科卒論生の米田舞美氏と協同で 行いました。記して謝意を表します。

注

注 1）内装や家具の色彩、反射率、光沢などによって、室内の輝度は異なる ため、同じ照明条件でも家具配置に影響を与えるという可能性はある。ただ し本実験では、模型内部に手を入れて家具を動かしながら配置を考えること から、テーブル面の明るさなど室内の照度をある程度実感でき、模型を外 から眺めるだけよりも室内の輝度に左右されにくいと考えられる。

注 2）縮尺模型と実空間 $(5 \mathrm{~m} \times 4 \mathrm{~m})$ で、「テーブルで食事をする」行為に対 する光量調節実験を行った（被験者 5 名）。その結果、適切な明るさとされ たのは、実空間ではテーブル面照度が約 100(Ix)のとき、縮尺模型では約 50(1x)のときとなった。照度值が低くなる主な原因として、模型の提示は無 空で暗室の実験室内で行なったことがあるものと考えられる。被験者は模型 を眺める距離や位置を変えるため、模型内の明るさに正確に順応しているわ けではないことと、模型内外での輝度対比が生じるということがある。

注 3）実験時に一人暮らしをしている被験者には、実家の家族と生活している ことを想定してもらった。実際に同居している家族は $3 \sim 5$ 名であった。

注 4）実験室と模型の明るさに順応してもららために 10 分間の時間をとることと した。

注 5）その他の教示として、「照明条件によって無理に異なる家具配置にする 必要はなく、各々の条件で本当にふさわしいと思うように配置すること」を伝 達した。

\section{参考文献}

1). 井上容子、大野治代 : 室内照度ならびに居住者の明るさに対する満足度 住宅内の照明環境に関する実態調査 (その1)、日本建築学会計画系論文 集、No.507、pp.1-5、1998.5

2）小林茂雄、乾正雄、中村芳樹、北村麻子：室内環境照明の明るさ、均 一さと生活行為の関係、日本建築学会計画系論文集、No.481、pp.13-22、 1996.3

3). 李善永、石原従道、平手小太郎、安岡正人 : 住宅居間における明るさの 分布が心理評価に及ぼす影響に関する研究、日本建築学会計画系論文 集、No497、pp.1-6、1997

4）稲垣卓造、飯島祥二：照明・色彩・光沢が室内の雾囲気評価之行為の選 択に与える影響、日本建築学会環境系論文集、No.570、pp.7-14、2003.8

5）三木保弘、戸倉三和子、淺田秀男、松下進 : 小型高効率ランプを用いた 多灯分散照明の提案とリビング・ダイニングにおける被験者評価及び省エネ ルギー性評価、日本建築学会環境系論文集、No.603、pp.92006.5

6）那須聖、斎藤雅也、宮川紅子 : 視野照度の比較による空の形態と人の椅 座位置の関係についての考察、日本建築学会計画系論文集、No.596、 pp.43-49、2005.10

7）小林茂雄、萩原利衣子：インテリアの内装色彩が家具の色彩選定とレイア ウトに与える影響 カフェの模型を用いた家具レイアウト実験による検討、日本 建築学会環境系論文集、No.571、pp.17-23、2003.9

8）山崎さゆり：生活時間のタイプ別事例分析 生活時間に基づく住居内の行 動々空間の対応関係に関する研究 その 3、日本建築学会計画系論文集、 No.538、pp.61-68、2000.12

（2006年12月 7 日原稿受理，2007年 6 月 22 日採用決定） 